\title{
Parametric Study on the Axial Behaviour of Concrete Filled Steel Tube (CFST) Columns
}

\author{
Raghabendra Yadav, Baochun Chen \\ College of Civil Engineering, Fuzhou University, Fuzhou, China
}

Email address:

raghabendrayadav@gmail.com (R. Yadav)

To cite this article:

Raghabendra Yadav, Baochun Chen. Parametric Study on the Axial Behaviour of Concrete Filled Steel Tube (CFST) Columns. American Journal of Applied Scientific Research. Vol. 3, No. 4, 2017, pp. 37-41. doi: 10.11648/j.ajasr.20170304.11

Received: October 27, 2016; Accepted: December 17, 2016; Published: November 15, 2017

\begin{abstract}
Concrete filled steel tube (CFST) columns are widely used in civil engineering structures due to its abundant structural benefits like excellent seismic behaviour, ultimate load bearing capacity, fire resistivity, excellent ductility and energy absorption capacity, particularly in zones of high seismic risk. Due to their excellent engineering properties, CFST columns are used in buildings, bridges, electric transmission line and offshore structures. The ultimate load carrying capacity of CFST columns depends upon various parameters such as D/t ratio, steel grade, concrete grade, etc. Abaqus software is used for the finite element modelling of CFST Columns. In this study the ultimate axial load carrying capacity of CFST column is investigated by changing diameter-to-thickness ( $\mathrm{D} / \mathrm{t}$ ) ratio, steel grade and concrete grade. Results shows that the ultimate load capacity decreases by increase in $\mathrm{D} / \mathrm{t}$ ratio but increases by increase in steel grade and concrete grade.
\end{abstract}

Keywords: CFST, Axial Behaviour, Parametric Study, Finite Element

\section{Introduction}

The CFST column has in the recent years evolved as alternative to the conventional methods in vogue [1-2]. A concrete-filled steel tubular (CFST) column is formed by filling a steel tube with concrete, as shown Figure 1. CFST columns are used in buildings, bridges, electric transmission lines and offshore structures [3-6] due to their abundant properties. Steel sections with concrete infill are being widely used as structural members, since filling the steel section with concrete increases both its strength and ductility without increasing the section size. Many researchers found that the CFST column system has numerous advantages compared with the ordinary steel or the reinforced concrete system due to its high-strength, stiffness, ductility, and better seismic performance [7-9]. Since the outside steel confines the concrete and the inside concrete prevents the steel from local buckling. The concrete is directly filled in the steel tube so the use of formwork can be discarded. The potential economical advantages of CFST columns in tall buildings could lead to significant savings of steel usage in comparison with pure steel columns. However, cement concrete has certain drawbacks like high shrinkage, creep and low tensile strength of cement concrete have lately been determined to significantly weaken the steel-concrete interface bond, thus hampering beneficial composite interaction, and resulting in the concrete transformation of some of its stress to the steel. The structural behavior of CFST elements are considerably affected by the difference between the Poisson's ratios of the steel tube and concrete core. In the initial stage of loading, the Poisson's ratio for the concrete is lower than that of steel. Thus, the steel tube has no confining effect on the concrete core. As longitudinal strain increases, the lateral expansion of concrete gradually becomes greater than expansion of steel tube.

The ultimate axial load carrying capacity of CFST columns are being affected by many parameters such as the diameter to the thickness ratio, steel grade and concrete grade [6]. This paper presents the effect of different parameters like diameter to thickness ratio, steel grade and concrete grade, on the axial load carrying of CFST columns.

\section{Modelling}

In order to simulate the actual behaviour of CFST columns, the main components of these columns have to be modelled properly. A simplified nonlinear finite element method was developed in this paper for circular CFST 
columns under the axial load loading. Abaqus is used for finite element model to efficiently predict the axial behaviour of the CFST column.

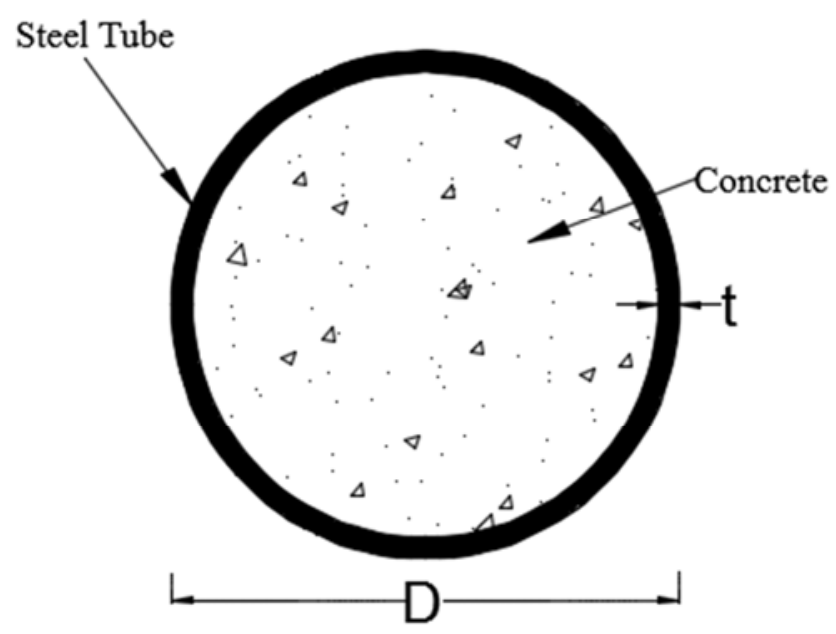

Figure 1. Cross Section of CFST Column.

The element library of finite element software ABAQUS 6.12-1 is used to select the type of element. Solid elements were found to be more efficient in modeling the steel tube and the concrete as well as it clearly defined boundaries of their elements. Three-dimensional eight-node solid element (C3D8) was used in this study.

To define the concrete behavior in the FE model, a stress strain diagram for the confined concrete should be established first. The equivalent stress-strain diagram for confined concrete under compressive loading, as shown in Figure 2 is used in the proposed FE model.

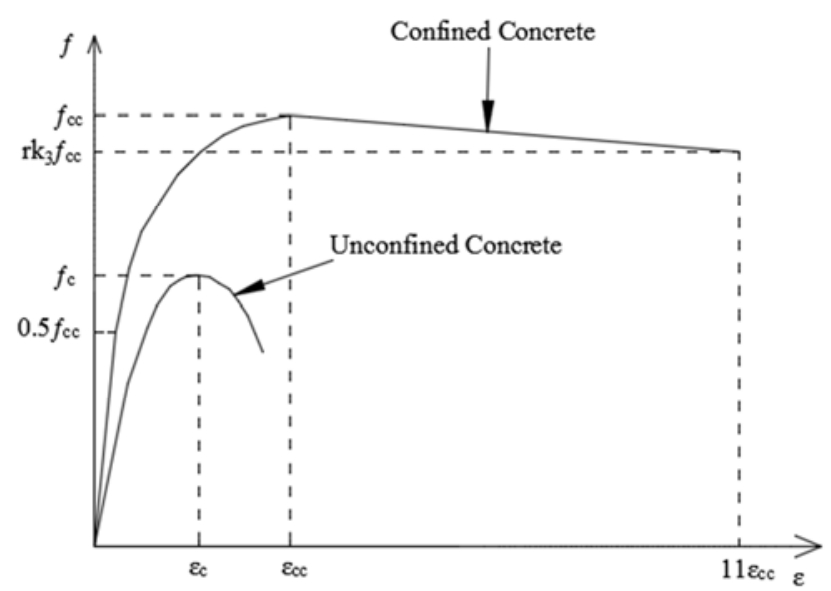

Figure 2. Equivalent stress-strain curves of unconfined and confined concrete.

Young's modulus $\left(E_{c c}\right)$, compressive strength $\left(f_{c k}\right)$, Poisson's ratio $(\mu)$ and tensile strength $\left(f_{t k}\right)$ of confined concrete are taken from GB50010 [10]. An elastic-plastic model with the von Mises yield criterion is used to describe the constitutive behavior of steel tube. The complete stressstrain relation obtained from uniaxial tension tests has been used in steel material model. Different properties of steel as, Young's modulus $\left(E_{s}\right)$, yield stress $\left(f_{y}\right)$, Poisson's ratio $(\mu)$ and ultimate stress $\left(f_{u}\right)$ are taken from GB50017 [11].

Displacement $\delta_{\mathrm{x}}=\delta_{\mathrm{y}}=\delta_{\mathrm{z}}=0$ is applied as boundary condition on the bottom end. The top end of the column is free, allowing displacement to take place in all directions. The uniform compressive loading in axial direction is applied on the top of column. The behavior of column when only Steel tube is loaded has been depicted with loading only Concrete section and loading on both concrete and steel tube section simultaneously and the combination gave higher ultimate loads. The base reactions and the top displacements are monitored.

The calculation involves one step of a static buckling analysis. Due to high nonlinearities at local and global levels, accompanying the traced inelastic, unstable and collapse behavior, Riks analysis was chosen as the solution. The Riks method is based on the concept of arc length as a measure of the solution progress in load-displacement configuration space. The increments are established automatically by the program. The user specifies only initial, minimum and maximum increments. The magnitude of an increment depends on the number of iterations and attempts, needed in the previous increment.

\section{Parametric Study}

Numerous experimental and analytical studies have been conducted to realize the behaviour of CFST columns with various sectional shapes, such as circular section [12-14], rectangular section [16-17], T shaped section [16] and double skin section [18]. Authors concluded that, the behaviour of CFST column is affected by the diameter to thickness ratio $(d / t)$, steel yield strength $\left(f_{y}\right)$, concrete compressive strength $\left(f_{\text {ck }}\right)$, axial compression ratio $(n)$ and slenderness ratio, for circular section and also depth to breadth ratio for rectangular section. Four different parameters are considered as stated above, having 13 numbers of specimens with the constant height of $400 \mathrm{~mm}$. Details of specimens and parameters are summarized in Table 1.

Table 1. Details of the Specimens considered for Analysis.

\begin{tabular}{lllll}
\hline Specimen no. & $\begin{array}{l}\text { Diameter } \\
(\mathbf{m m})\end{array}$ & $\begin{array}{l}\text { Thickness } \\
(\mathbf{m m})\end{array}$ & $\begin{array}{l}\text { Steel } \\
\text { Grade }\end{array}$ & $\begin{array}{l}\text { Concrete } \\
\text { Grade }\end{array}$ \\
\hline S1 & 150 & 1.2 & Q345 & C50 \\
S2 & 150 & 2 & Q345 & C50 \\
S3 & 150 & 4 & Q345 & C50 \\
S4 & 150 & 6 & Q345 & C50 \\
S5 & 150 & 8 & Q345 & C50 \\
S6 & 150 & 10 & Q345 & C50 \\
S7 & 150 & 2 & Q235 & C50 \\
S8 & 150 & 2 & Q390 & C50 \\
S9 & 150 & 2 & Q420 & C50 \\
S10 & 150 & 2 & Q345 & C30 \\
S11 & 150 & 2 & Q345 & C40 \\
S12 & 150 & 2 & Q345 & C60 \\
S13 & 150 & 2 & Q345 & C70 \\
\hline
\end{tabular}

\section{Results and Discussions}

Numerical analysis of CFST columns was done using 
Abaqus. The effect of different parameters on the ultimate axial load carrying capacity of CFST columns are illustrated below:

\subsection{Diameter to Thickness Ratio}

This study is conducted on six circular CFST columns to investigate the effect of thickness variation on the performance of column. $\mathrm{D} / \mathrm{t}$ ratio in this study ranges from 15 to 125 . Increase in $\mathrm{D} / \mathrm{t}$ ratio may be either due to the increase in diameter or due to the decrease in thickness of the section. Hence it is analysed by keeping the diameter constant and varying the thickness. The increase in $\mathrm{D} / \mathrm{t}$ ratio with increased thickness for a constant diameter represents the improvement in cross section of the steel tube and hence produces greater section capacity. Figure 3 shows the load displacement curve and the Figure 4 shows the effect of variation of diameter to thickness ratio on the ultimate load carrying capacity of CFST columns. The results shows that the ultimate axial load carrying capacity of CFST columns increases with the decrease in the diameter to the thickness ratio of the columns. The axial capacity of a CFST columns can be increases by increasing the thickness of the steel tube without increasing the total diameter of the column. When the $\mathrm{D} / \mathrm{t}$ ratio is increased from 15 to 125 , the ultimate load carrying capacity of the column is found to decrease by $67.9 \%$.

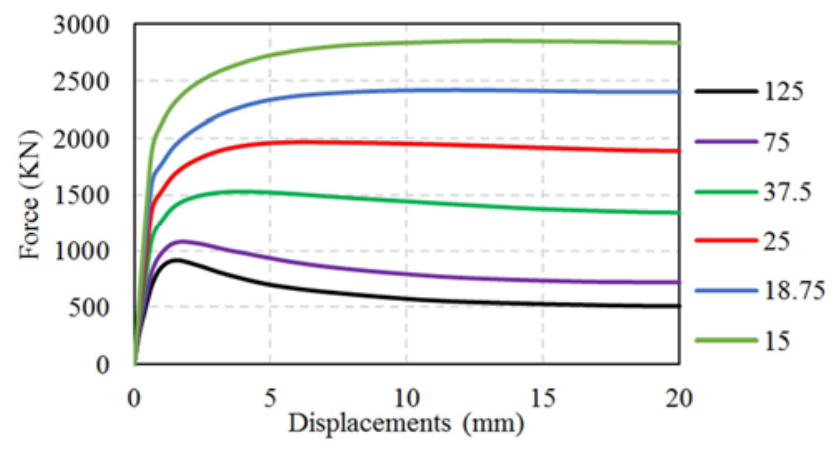

Figure 3. Load-displacement curves for different D/t ratio.

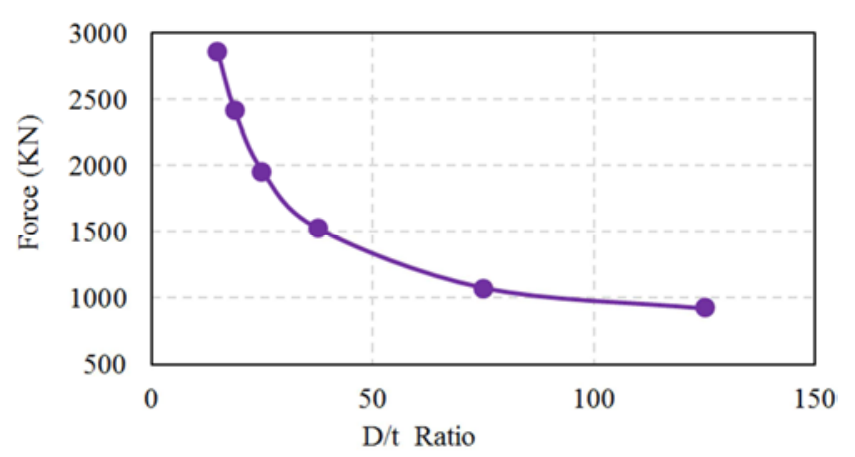

Figure 4. Effect of Thickness variation of steel tube on loading carrying capacity.

\subsection{Grade of Steel}

Four circular CFST columns are modelled to investigate the effect of variation of steel grade on the axial performances. The capacity of CFST column is decided by the yield strength of steel. The ultimate load of columns is found to increase significantly with an increase in the steel yield strength. Figure 5 shows the load displacement curve and the Figure 6 shows the effect of variation of grade of steel on the ultimate load carrying capacity of CFST columns. The results shows that the ultimate axial load carrying capacity of CFST columns increases with the increase in the yield strength of steel. The load carrying capacity increases linearly. The load carrying capacity decreases exponentially. The ultimate load carrying capacity of the column is found to increase by $25.4 \%$ with the increment of steel yield strength from $235 \mathrm{MPa}$ to $420 \mathrm{MPa}$.

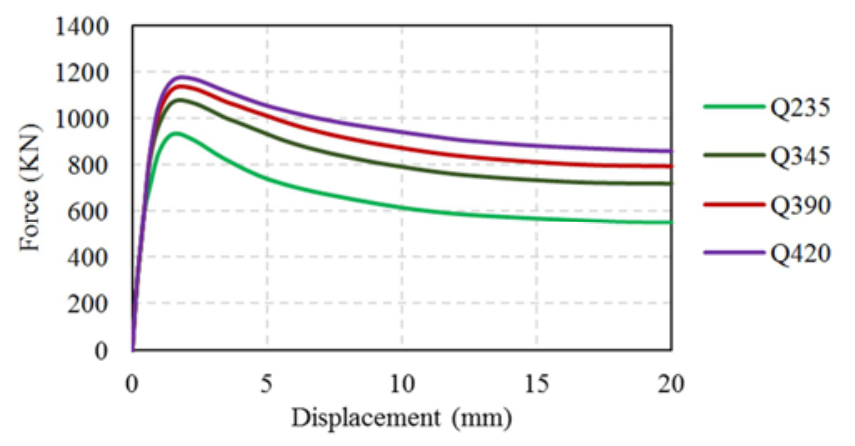

Figure 5. Load-displacement curves for different Grade of Steel.

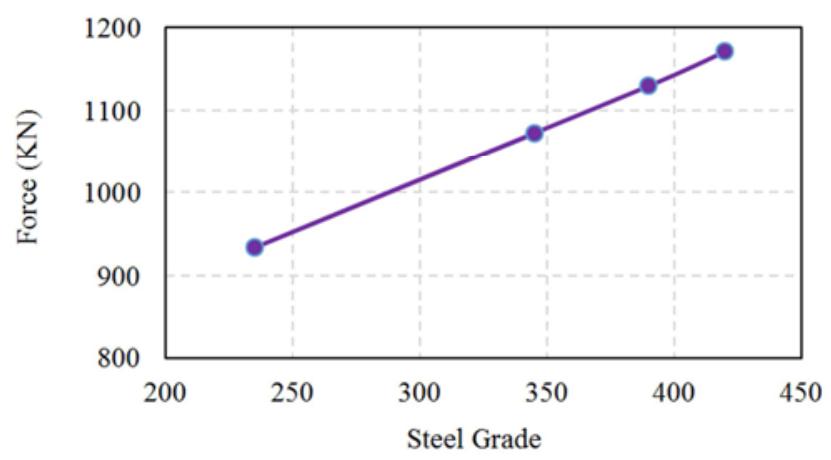

Figure 6. Effect of Grade variation of Steel on loading carrying capacity.

\subsection{Grade of Concrete}

For this modelling five circular CFST piers are modelled to investigate the effect of variation of concrete on the axial performances. The strength of concrete core decides stiffness of CFST columns. Stiffness increases with increase in concrete strength but columns fail due to crushing of concrete exhibiting brittle behaviour when filled with high strength concrete. But it is a fact that increase in concrete core strength increases the strength of filled columns to a larger extent, no matter of either $D / t$ ratio or $\mathrm{L} / \mathrm{D}$ ratio. The ultimate axial loads of CFST columns increases with an increment in the concrete compressive strength. Figure 7 shows the load displacement curve and the Figure 8 shows the effect of variation of grade of concrete on the ultimate load carrying capacity of CFST columns. The ultimate load carrying capacity of 
CFST columns increases with an increment in the concrete compressive strength. The load carrying capacity increases linearly. Increasing the concrete compressive strength from $30 \mathrm{MPa}$ to $70 \mathrm{MPa}$ increases the ultimate load carrying capacity by $54.3 \%$.

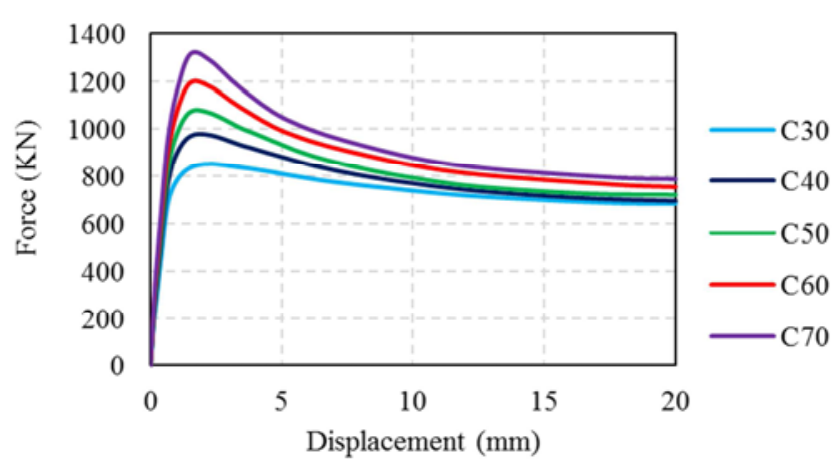

Figure 7. Load-displacement curves for different Grade of Concrete.

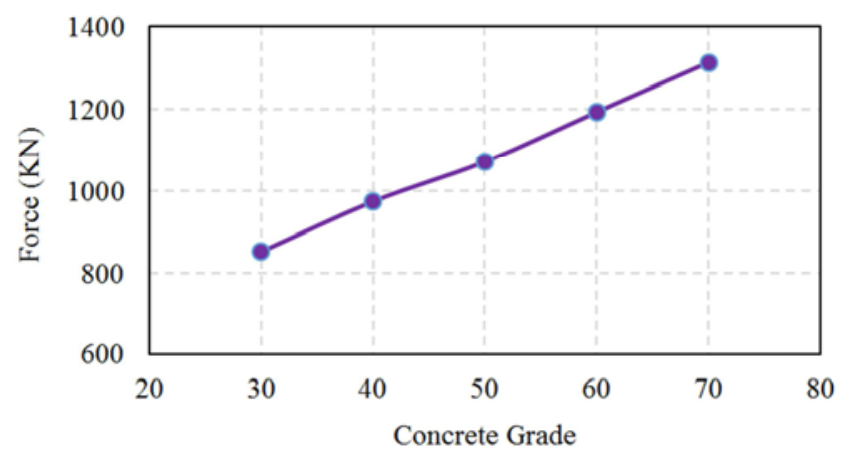

Figure 8. Effect of Grade variation of concrete on loading carrying capacity.

\section{Conclusions}

This paper presents a numerical model for the nonlinear inelastic analysis of thin-walled circular CFST columns under uniform axial load. Based on the parametric study, the following important conclusions are drawn:

a) The ultimate load capacity of a CFST columns can be significantly increased by a smaller $\mathrm{D} / \mathrm{t}$ ratio for the crosssection in the design.

b) The steel yield strength is independent on the initial flexural stiffness of the columns. However, the ultimate load carrying of column is directly proportional with steel yield strength.

c) The initial stiffness of the columns increases slightly due to the use of high strength concrete. Further, use of high strength concrete leads to increase in the load carrying capacity.

\section{Acknowledgements}

This research described here was sponsored in part by the National Science Foundation under Grant No.51178118 and Fuzhou University as well as the SIBERC (Sustainable and Innovative Bridge Engineering Research Center), China. Their support is gratefully acknowledged. The opinions expressed in this paper are those of the authors and do not necessarily reflect the views of the sponsors. The Authors also like to thanks Bhawana Rauniyar, Santosh Bhattarai and Subhash Pantha for their valuable suggestions and supports.

\section{References}

[1] P. K. Gupta, S. M. Sarda and M. S. Kumar (2007), "Experimental and Computational Study of Concrete Filled Steel Tubular Columns under Axial Loads", J. of Const. Steel Research, 182-193.

[2] N. K. Brown, M. J. Kowalsky and J. M. Nau (2015), "Impact of $\mathrm{D} / \mathrm{t}$ on seismic behavior of reinforced concrete filled steel tubes", Journal of Constructional Steel Research 107, 111-123.

[3] R. Yadav, B. Chen, Y. Huihui and Z. Lian (2016), "Numerical Study on the Seismic Behavior of CFST Columns", 11th Pacific Structural Steel Conference, Shanghai, China, October 2931, pp. 360-369.

[4] M. Dundu (2012), "Compressive strength of circular concrete filled steel tube columns", Thin-Walled Structures 56, 62-70.

[5] K. Nakanishi, T. Kitada, H. Nakai (1999), "Experimental study on ultimate strength and ductility of concrete filled steel columns under strong earthquake", Journal of Constructional Steel Research 51, 297-319.

[6] M. Bruneau, and J. Marson (2004), "Seismic Design of Concrete-Filled Circular Steel Bridge Piers", J. Bridge Eng. 9: 24-34.

[7] B. Chen, T. L. Wang, Overview of Concrete Filled Steel Tube Arch Bridges in China, Practice Periodical on Structural Design and Construction, ASCE, May 2009, 14 (2): 70-80.

[8] L. H. Han, W. Li and R. Bjorhovde (2014), "Developments and advanced applications of concrete-filled steel tubular (CFST) structures: Members", J. of Const. Steel Research $100,211-228$.

[9] R. Yadav, B. Chen, H. Yuan and R. Adhikari (2016), "Comparative Analysis of Reinforced Concrete Buildings and Concrete Filled Steel Tube Buildings in Nepal", International Conference on Earthquake Engineering and Post Disaster Reconstruction Planning, Nepal, pp. 70-77.

[10] China National Standard, (2010), Code for Design of Concrete Structure, GB 50010-2010, China Architecture \& Building Press, Beijing, China. [In Chinese].

[11] China National Standard, (2003), Code for Design of Steel Structure, GB 50017-2003, China Architecture \& Building Press, Beijing, China. [In Chinese].

[12] K. A. S. Susantha, T. Aoki and M. Hattori, (2008), "Seismic performance improvement of circular steel columns using precompressed concrete-filled steel tube", J. of const. steel research, 64, 30-36.

[13] J. F. Hajjar and C. Tort, (2010), "Mixed finite-element modelling of rectangular concrete-filled Steel tube members and frames under static and dynamic loads", Journal of Structural Engineering, ASCE, 136, 6, 654-664.

[14] Y. Xiao, Z. X. Zhang, S. K. Kunnath and P. X. Guo, (2011), "Seismic behavior of CFT column and steel pile footings", Journal of Bridge Engineering, ASCE, 16, 5, 575-586. 
[15] H. B. Ge and T. Usami, (1996), "Cyclic test of concrete filled steel box columns", Journal of Structural Engineering, ASCE, $122,10,1169-1177$.

[16] L. H. Han, Y. F. Yang and Z. Tao, (2003), "Concrete-filled thin-walled steel SHS and RHS beam-columns subjected to cyclic loading", Thin Walled Structures, 41, 9, 801-833.
[17] Y. Q. Tu, Y. F. Shen, Y. G. Zeng and L. Y. Ma, (2014), "Hysteretic behavior of multi-cell T-shaped concrete-filled steel tubular columns", Thin walled Structures, 85, 106-116.

[18] L. H. Han, H. Huang and X. L. Zhao, (2009), “Analytical behaviour of concrete-filled double skin steel tubular (CFDST) beam-columns under cyclic loading", Thin Walled Structures 47, 6-7, 668-680. 